\title{
"Eyes Have No Border". Presencing the Slovenian-Hungarian Border in Goričko and the Rába Valley
}

Received: April 16, 2020 • Accepted: June 23, 2020

\author{
Ingrid Slavec Gradišnik - Katalin Munda Hirnök \\ ZRC SAZU Institute of Slovenian Ethnology, Ljubljana - Institute for Ethnic Studies, Ljubljana
}

\begin{abstract}
The article draws on the written and oral memories of people living along the border between Slovenia (Goričko in Prekmurje) and Hungary (the Rába Valley). They are presented as comments on a century-long process of political changes in this borderland and demonstrate a plethora of ways in which border shifts intrude on people's everyday lives. People's concern with the border is reflected in the fact that it is a topic that emerges in any conversation with individuals living next to it, whether in the context of work, family, daily errands or stories of the past and present. In this article, informed by two concepts-border and memory- we present memories and perceptions of the border as they are expressed in casual comments or observations and semi-structured conversations with interviewees in the field. Life in borderlands is always localized, and there are visible divergences in the experience of the border on the Slovenian and Hungarian side. In Prekmurje, historical events along the border, especially the post-Trianon one, and the memory of these events are perpetuated through anniversaries of the annexation of Prekmurje to the Kingdom of SCS, whereas in the Rába Valley, memories especially relate to the Iron Curtain period. In a much more poignant way, they also constitute the present Slovenian community in ethnic terms as they are mediated in their vernacular.
\end{abstract}

Keywords: Slovenian-Hungarian border, memory, past presencing, Rába Valley, Goričko

The border, which primarily symbolizes the physical strength of a country, is a dominant subject for the people populating borderlands across the world (DoNNAN WILSON 1999:1): "Borders are also meaning-making and meaning-carrying entities, parts of cultural landscapes which often transcend the physical limits of the state and defy the power of state institutions" (DONNAN - WILSON 1999:4). That is precisely what the border between the Yugoslavian and Hungarian states represented, as did the border between Hungary and Austria, especially following 1948. The hermetic border installed after the Cominform dispute between Tito and Stalin impressed itself most in the individual and collective memory of the borderland population: people had already lived in separate states before the great schism, but despite the fact that the border was guarded, it had been porous to daily and seasonal work 
migrations and family connections - whereas the Iron Curtain radically severed the places and spaces of the regional economy and social life. ${ }^{1}$

Our field research was endowed by the research of historians, geographers, sociologists, linguists, and ethnologists. It was carried out in the villages of the northern Goričko region in Prekmurje (Slovenia), by the border with Hungary, and among Slovenians in the Rába Valley in Hungary. Our preceding research, ${ }^{2}$ primarily concerning the significance of the post-1990 Slovenian-Hungarian border and its impacts on the population, particularly with regards to mobility, communication and other integration processes in the area of the invisible (open) European border, made it apparent that "despite many positive changes that have enabled and facilitated cross-border mobility, communication and contacts between people and institutions (...), the state border remains alive in both the memory and everyday experiences of individuals." (MUNDA HIRNÖK - MEDVEŠEK 2016:90).

People's concern with the border is further reflected in the fact that the border is a topic that sooner or later emerges in any conversation with the people living next to it, whether in the context of work, family, daily errands or stories of the past and present. In this article, we present perceptions of the border as they are expressed in casual comments or observations and conversations with our interviewees in the field.

Two complex concepts inform our research: border and memory. Both resonate in contemporary social science and humanities research and are corroborated by the boom of two extensive research fields that have in recent decades evolved around these two concepts, namely border studies and memory studies. Rather than operating within a rigid framework, borders and memory reverberate more closely with interdisciplinary or transdisciplinary scholarship (e.g. WILSON - DONNAN 2012; ERLL - NÜNNING 2010; GREEN 2012a, 2013; MACDONALD 2013). Notwithstanding the numerous discussions on and definitions of these two concepts, as well as the knowledge fields developing in parallel, they are predominantly located in the anthropological horizon, drawing on the anthropology of place and space (e.g. Low - LAWRENCE-ZÚÑIGA 2003), the anthropology of borders (e.g. Donnan - Wilson 1994; Newman 2011; WASTL-WaLter 2011; Spalová - Grygar 2006; Wilson - Donnan 2012; Sevastianov et al. 2015; Donnan et al. 2017), and identity studies of the border areas (e.g. WILSON - DonNAN 1998; DonNaN - WILSON 1999). From the macro-perspective of politics and history, focus thus shifts to the micro-perspective of individual and collective experience, emotions and identities.

In the present case, we abstain from questioning aspects of identity. Given the fact that at this time a physical border no longer exists, our focus is neither ethnic identifications nor some newly arising de-territorialized identities (in which, to note, the role of culture and the state and its institutions in the daily life of citizens is frequently underestimated;

1 The article is a revised part of a longer paper (Munda HiRnöK - SLAVEC GRAdišNiK 2019), based on research carried out in the framework of the research project Protected Areas along the Slovenian-Hungarian Border: Challenges of Cooperation and Sustainable Development (J6-4620, 2017-2020) (see more: FIKFAK - MÉszÁRos 2019) and the research program Cultural Spaces and Practices: Ethnology and Folklore Studies (P6-0088, 2015-2021), both sponsored by the Slovenian Research Agency.

2 The project Mobility, Integration and Adaptation along the Hungarian-Slovenian Border (20132015) was supported by the Slovenian Academy of Sciences and Arts in Ljubljana and the Hungarian Academy of Sciences in Budapest (cf. MundA HirnöK - MedvešEK 2016). 
WiLSON - DonNAN 1998:2; cf. WiLSON 2012:164). Rather, we are interested in how historical facts (see MUNDA HIRNÖK - SLAVEC GRADIŠNIK 2019, 2020) are imprinted into the fabrics of the experiences, knowledge and perceptions of people living in the border area. The fact that they speak about the border in various contexts served as a reminder to question how the border affected and still affects people's daily life. These topics are significant for their primary aspect, which is political: a border is drawn on the map to separate two nation-states, in this way co-existing and competing with "the symbolic boundaries of identity and culture which make nations and states two very different entities" (WILSON - DONNAN 1998:2). ${ }^{3}$

In this spirit, the anthropology of borders warns "that nations and states, and their institutions, are composed of people who cannot or should not be reduced to the images which are constructed by the state, the media or by any other groups who wish to represent them" (WILSON - DonNan 1998:4). This is of salient importance as it keeps attention on those institutions and infrastructure able to bolster or weaken the self-esteem of the people and regions, thus contributing to the reproduction or transformation of their being in the world and their identity. ${ }^{4}$ Here the term "groups" relates to both geographical as well as ethnic criteria: Goričko, as well as the Rába Valley, have long been considered remote, forgotten regions, in addition to the fact that the larger area is home to the Hungarian minority in Slovenia, ${ }^{5}$ and the Slovenian minority in Hungary. On the other hand, we focus our primary attention to our collocutors as individuals.

\begin{abstract}
"When ethnographers study border peoples, they do so with the intention of narrating the experiences of individuals who often are comfortable with the notion that they are tied culturally to many other people in neighbouring states. An anthropology of borders simultaneously explores the cultural permeability of borders, the adaptability of border peoples in their attempts ideologically to construct political divides, and the rigidity of some states in their efforts to control the cultural fields which transcend their borders. Anthropologists thus study the social and economic forces which demand that a variety of political and cultural boundaries be constructed and crossed in the everyday lives of border people." (WILSON - DonNAN 1998:4)
\end{abstract}

In the continuation of this article, the border is thus understood as a boundary which is not only political but primarily experiential. The meanings attached to the border by the inhabitants of the Slovenian-Hungarian borderland speak of the social and symbolic powers of borders, voiced in their narrations about the past and present, possibly also the future (cf. MACDONALD 2013:216; SVENŠEK 2019). In this sense, life in the borderlands frequently exhibits a different, specific historical and social dynamic compared to state centers. Thus, we speak not only of the spatial aspects of the border but also of its temporalities. We observed border temporalities on two levels: by following the

\footnotetext{
3 This is significant for a broader discussion on this specific borderland due to its ethnically mixed population (the Slovenian minority in the Rába Valley in Hungary and the Hungarian minority in the south-east of Prekmurje), and the future of this region and comparable ones in contemporary Europe (WILSON 2012).

4 How political and media discourse have shaped and reproduced the perception and self-perception of Prekmurje and its people as a "different" landscape was analyzed by Sandra KošTrIC (2011).

5 We did not include the Hungarian minority in our research.
} 
chronology of shifts on the Slovenian-Hungarian border (Munda HIRNÖK - SLAVEC GRADIŠNIK 2019, 2020), and by placing individual narratives of the border in the time frame between the Trianon Peace Treaty, the Iron Curtain and Europe without borders in the $21^{\text {st }}$ century - between then and now or now and then. As our field material shows, narrating the past has become part of what we are accustomed to interpreting as social or collective memory. Therefore, border narratives move between first-hand experience and mediated memory, i.e. between experiential and discursive aspects carried by the reproduction of memory that informs interpretations of the boundary phenomenon.

The presented experiences and reflections of life along the border are based on material collected during fieldwork in the mentioned research projects between 2013 and 2018 (see footnotes 1 and 2). The semi-structured interviews with Slovenians from the extreme northeastern Goričko and from the Rába Valley regions, collected in May 2018, comprise the most relevant material for this text. ${ }^{6}$ We chose these areas because their inhabitants were most directly confronted with the border in physical terms. ${ }^{7}$ Our interviewees in the Rába Valley were mostly educated locals. In the case of the Goričko villages, we mostly conversed with people who made a living from self-sufficient farming with the aid of savings earned through past work abroad and, we assume, the support of younger family members, who are seasonally or permanently employed abroad. Other subjects included an entrepreneur and several interviewees outside the agriculture domain. All were born after the Second World War; approximately half were women, the other half men. With a loosely structured questionnaire, we directed our conversations to border issues, but we deliberately left them a fair amount of freedom to talk about their life experiences in this area in broader terms. All interviewees spoke in their vernacular, which is markedly different from standard Slovenian, a circumstance facilitated by the fact that one of the researchers was born in the Rába Valley.

\title{
LOCATIONS OF MEMORIES
}

\begin{abstract}
"Before the First World War, you see, it was ... all the same landscape, essentially. It was the Slovenian March belonging to the Hungarian crown for the most part, for which the mentality of these people somehow differed a little from all the other Slovenians (...) after all, the government here was Hungarian, and the upper classes were also Hungarian (...) In some way, the folks of these parts, especially the people of Rába Valley, but also of Prekmurje, whether they like it or not, (...) this history has shaped their character in a particular way (...): after all, when you're under a foreign, how to say, perhaps not exactly boot heel but, the social pressure of a governing nation speaking a different language, for example, it influences one's mindset. There's a type of ancestral fear still haunting the folks of Rába Valley, especially the older generations, yes, and that's where it has its roots. In a thousand years of coexistence, or non-coexistence with the Hungarians, no? Since here, the Hungarians were always in a way
\end{abstract}

${ }_{6}$ Field sources are marked as FN (field note), followed by the year of record and the initials of the interviewee.

7 These include the villages of Dolenci, Budinci, Markovci, Trdkova, and Martinje on the Slovenian side, as well as Felsőszölnök/Gornji Senik, Orfalu/Andovci, and Szentgotthárd/Monošter on the Hungarian side.) 
a superior, dominant nation, or at least that's how they carried themselves and behaved. And then, well, you're left on this side of the border suddenly, after 1920, just a handful of folks, stranded, and in general, this had always been the margins, yes? The Rába Valley was always a fringe space, and then, they [people of Prekmurje] leave, yes, and you're stuck over here. I think it was a completely disoriented situation back then. And after ' 45 , yes, when the borders were back, they were left beheaded so to speak, there was no intelligentsia of their own ... it was just ordinary, rural folks, mostly resigned to their fate.” (FN 2014_MS)

The extensive quote above, from a story related by an educated woman, is not a memory piece but rather a narrated reflection on local existential experience-we might refer to it as historical consciousness (cf. MACDONALD 2012:235). Beyond the implementation of the Trianon border of 1920, and the Iron Curtain of 1948, it was also profoundly marked by the pre-existing relations between Slovenians and Hungarians in the old Hungarian state. Before the end of the First World War, when Slovenians represented a majority population in the westernmost area of the Hungarian part of the Dual Monarchy, the borders present were not administrative, but rather ethno-national, linguistic and social. These boundaries were further reinforced by the marginal geographical location and power relations between the majority and the minority.

Holding broad self-reflection of the type above is inconceivable without education and the circulation of knowledge in oral or written words. In general, people we spoke with on both sides of the border maintained they had not learned about Slovenian history in school and had only "heard" what they knew of it. Exceptions are the accounts of a few representatives of the local intelligentsia who were, or still are, deeply interested in the past of the immediate local or larger environment; from their narratives and comments we can sense the interest in eavesdropping to stories told by others, yet also knowledge of history secured by schooling.

Among the Rába Valley Slovenians, encouraging education was more an exception rather than the rule up until the 1970s. In the early 1970s, secondary school graduates began completing their studies in Slovenia. Several graduates who joined academia at the High School for Teachers in Szombathely, or in Györ, returned to the Rába Valley, where they continue to strengthen the Slovenian community, managing its central organizations, namely the Association of Slovenians in Hungary (established in 1990) and the National Slovenian Self-Government (1995), the publication of the gazette Porabje (1991), conducting the program of Radio Monošter [Radio Szentgotthárd] (2000) and the telecast Slovenski utrinki [Slovenian Moments] (1992), running the Slovenian Cultural and Information Center (1998) and various cultural groups, organizing events, supporting economic development and striving for close bonds with Slovenia.

This infrastructural framework is significant as, in comparison to Prekmurje, it creates an important communication arena for Slovenians as a minority in the Rába Valley, a place for the preservation, reproduction, transformation, and communication of experiences. Here, it is more than just verbal narratives that pass between mouth and mouth, eye to eye. Suddenly, they emerge on radio, appear in print or on book pages so they may again flow into everyday use. Without these efforts, the stories of the border would not have reached younger generations born after 1990: 


\begin{abstract}
"Yes, they still speak of it much [the elderly on the subject], I hear them chat amongst themselves, or on Radio Monošter [Szentgotthárd] which we like to listen to, our radio for the Slovenians here in Porabje. It's frequently a subject on there, older people talking about the old days when they lived by the border and couldn't get across, even to visit their relatives." (FN 2014_MZ)

“(...) our radio [is based on] listening and asking, asking these older people, since they're about to go, so to say ... These people still speak that dialect of ours, still, the home tongue, and they have much to tell about the old times, and the border times." (FN 2014_MM)
\end{abstract}

There are visible divergences in the thematization of the border on the Slovenian and Hungarian side. In Prekmurje, historical events by the border, especially Trianon, and the memory of these events are perpetuated through jubilee anniversaries of the annexation of Prekmurje to the Kingdom of SCS, particularly prominent during the $100^{\text {th }}$ anniversary last year. In the Rába Valley, however, border memories originate bottomup: so the people do not forget, so young become aware of their history and may be able to know and believe that these events, which did not unravel in their lifetimes, had indeed occurred and are preserved in their mother language - the Slovenian vernacular of the Rába Valley (FN 2014_MM).

Younger collocutors likewise point at forgetting, implicitly linked to remembrance and loss:

\footnotetext{
"It's crazy that when you're little, you don't understand it, you don't ask the grandparents about all those things they had to suffer. (...) Now as I'm older, I'd be interested, really, but my folks are no longer around ... and so I can't ask them about life, how it was back then. (...) Back then as a kid (...), these are things people simply forget. Or we haven't even considered the value of asking about it, and perhaps writing it down.” (FN 2018_VK)
}

\title{
THE POST-TRIANON FRAGMENTS
}

To flesh out the sparse and transmitted memories of our respondents, we here rely on a few representative records from the contemporary press. These corroborate historical accounts that the Trianon border caused considerable unrest among people with the new authorities in Hungary, Austria and the Kingdom of SCS, and uncertainty among people left divided on both sides of the border. Facing their new realities was no easy ordeal, which points at the particular nature of the relation between the peace treaty border delineation as a binding legal act and real life conditions in the region the new border cut through (cf. Munda HiRnÖK - SLAVEC GRADIŠNIK 2020).

Roughly one year after the implementation of the Trianon border, the Prekmurski Glasnik gazette reported that the boundary alongside which the commissions were placing the boundary stones was indeed definitive and had to be respected. The people ought not to be fooled by the "troublemakers", who "out of inborn malice provoked and incited the folk of Prekmurje, falsely claiming the region shall again belong under Hungary. The folks, tired of being now on one side, now on the other side of the border, 
were growing mighty mistrustful." Besides, the instigators harassed the demarcation commission during its placement of border stones. ${ }^{8}$

The press pointed out the fact that Yugoslavian forces had crossed the former AustroHungarian border on 12 August 1919, which shall thus "remain a historical day", marking their birth as "free citizens" with civic duties, among which were not to be found, conversely, such "fantastic rights" as:

\begin{abstract}
"Dreaming naively of their own parish, (...) all for themselves with special rights (...) and get us into even more trouble than we had been in at the start of 1919. Those brothers of ours forgot themselves even so far as to begin making the pact with our enemies, the Hungarians and their henchmen, who can hardly wait to subjugate us once again, so as to treat us even worse than they had been treating us before our liberation on 12 August 1919."'9
\end{abstract}

Hungary also had its objections, as evident from the following report:

\begin{abstract}
"Voices are heard that the Hungarians wish to get back Lower Lendava and certain nearby villages and that in return they are offering us the lands from the river Rába to Szentgotthárd. Our state will not hear of it, we want borders as it was written in the Trianon contract." 10 Formally it seemed the demarcation commission "might correct the border where injustices are found, yet only with express permission from both Yugoslavia and Hungary. Both states must agree, not only one."11
\end{abstract}

From this perspective, the final implementation of the new border emerges as a negotiation process involving the authorities, the border demarcation commission - conducting field activities in Prekmurje till the late autumn of 1921 - and the interests of locals. As part of its procedure, the commission inquired on the latter. On its request, the district authorities of Murska Sobota demanded from the mayors of frontier municipalities' answers to questions concerning the crucial interests of the inhabitants. The questionnaire was focused on public awareness of the border's course; about any property owned by the municipality across the border (where and how much); whether the border divided any roads or popular routes; whether the municipality had on its side power generators, water supply, sawmills, mills; the location of the church, the graveyard, the school, the hospital; the source of its wood for construction and energy; the fairs frequented by locals; the products they sold or bought; the existence of an agricultural or workers' cooperative; its seat; how many Hungarians and how many Slovenians lived in the municipality; whether the Hungarians were indigenous or settled; how long Slovenians had been living in the area; what the villagers' religion was; whether the border interfered with established hunting, agriculture or fishing practices; etc. ${ }^{12}$

\footnotetext{
${ }^{8}$ Ugotovitev Jugoslovansko-Madžarske meje [The Setting of the Yugoslavian-Hungarian State Border]. Prekmurski glasnik 2(20), 31. 7. 1921:1.

9 Druga obletnica [The Second Anniversary]. Prekmurski glasnik 2(22), 14. 8. 1921:1.

10 Granice Jugoslavije [Borders of Yugoslavia]. Prekmurski glasnik 2(25), 4. 9. 1921:3.

11 Spremna nota [Preface]. Prekmurski glasnik 2 (28), 25. 9. 1921:2.

12 Pitanja za obmejne občine [Questions for the Frontier Municipalities]. Prekmurski glasnik 2(28), 25. 9. 1921:2; cf. Kozar 2017.
} 
Hungary, on the other hand, appeared far more concerned with preventing Austria from claiming Burgenland than dealing with border decisions along the Slovenian section of Yugoslavia. When the Austrians began to occupy the region, Hungarians left behind raiding gangs that skirmished with the Austrian gendarmerie, ${ }^{13}$ preventing the submission of Hungary's westernmost settlements to Austria while demanding a new agreement between the states. The people of Prekmurje held fast: "Rowdy opposition is of no use; the contract is done and must be enacted." 14

It was in the interest of the Prekmurje population to immediately formalize the northern border with Austria as well, "so that it corresponds appropriately to national, political, economic and strategic realities". However, this issue was the demarcation of the Austrian-Hungarian border, the southern boundary of which was the Rába River. Thus, Hungarians kept a "wedge" of territory between the northern Yugoslavian border and the Rába: "some 8 to 10 kilometers wide, and some 18 to 20 in length. This border is unnatural as well as economically and strategically unsound. Therefore, we demand that this strip of land also be given to us, so that the common northern border between Yugoslavia and German Austria is the river Rába." 15

Great interest in the demarcation process was also expressed by the Slovenians left behind in Hungary, pleading with the commission to annex them to Yugoslavia after all, "for we are Slovenians and do not wish to reside in the crumbled Hungary." 16 Nevertheless, the initial decision was upheld.

Quoted fragments from the contemporary press shed light on the historical facts illustrating the spirit which leaves no immediate traces in living memory-only descendants of the witnesses remain. In their accounts, they speak of family histories, of husbands or wives living across the border, of the hardships of the local life which compelled people to seek a living wage through seasonal work abroad or emigration and, occasionally, illegal activity as well (cf. PŠAJD 2007; SEDAR 2014). If the narratives nowadays are being reproduced by modern media, especially the press, radio and television, decades ago people still narrated about the time before the First World War, when the area of the present day Rába Valley and Prekmurje was a singular Slovenian region in the Hungarian part of the monarchy (RAVNIK 1999:333).

Narratives recorded in the field a few decades ago point to the identity ambivalences of the Prekmurje people: "in the Kingdom of SCS [it was] 'hard enough to accept we were Slovenes, and when we got finally used to it we were forced to become Hungarian again"” (BRUMEN 1992:20). ${ }^{17}$ The Trianon border severed Markovci and some other villages (Čepinci, Budinci, Dolenci) in northern Goričko from their hinterlands, the Rába Valley ${ }_{1}^{18}$ where the people traditionally traded, wed, visited, celebrated and, in short, felt at home since in Felsőszölnök/Gornji Senik, in Apátistvánfalva/Števanovci, Orfalu /Andovci, Permise/Verica and Ritkaháza/Ritkarovci folks spoke the same language

13 Zapádna Ogrska [Western Hungary]. Prekmurski glasnik 2(25), 4. 9. 1921:3.

14 Madžari bodo izročili Zapádno Ogrsko Austriji [Hungarians Will Relinquish Western Hungary to Austria]. Prekmurski glasnik 2(20), 31. 7. 1921:3.

15 Razmejitev v Prekmurju [Demarcation in Prekmurje]. Prekmurski glasnik 2(26), 11. 9. 1921:2.

16 Slovenci na Madžarskem prosijo za sprejem v Jugoslavijo [Slovenians in Hungary ask to join Yugoslavia]. Prekmurski glasnik 2(28), 25. 9. 1921:2; cf. Kozar 2017:24.

17 The second part of the statement refers to the Hungarian occupation during the Second World War.

18 Markovci is $13 \mathrm{~km}$ from Szentgotthárd and $34 \mathrm{~km}$ rom Murska Sobota. 
and were Catholic. ${ }^{19}$ Though the inhabitants of Goričko could barely comprehend the standard Slovenian language and were rather distrustful of the new state, they were hostile to Hungarians, did not identify as Hungarians themselves and also refused to accept the name "Wends") (BRUMEN 1992:21; cf. KoZAR 2017:25; FN 2018 KK).

Not only in the religious aspect but in general, people in the northern villages of Goričko had historically gravitated towards Hungary and Austria: ${ }^{20}$

\begin{abstract}
"It was all connected in that direction. When they had to visit a government office or whatever, they went to Szentgotthárd, or they went to Jennersdorf, to visit a doctor, for example, is where they went to and not Murska Sobota. (...) The border was there, some kind of regime, but some people chose to ignore it. They weren't used to not being able to go into their forest, say, or a store. Besides (...) the black market was thriving. They smuggled eggs, tobacco, general goods. There was control on the border, though. Financial customs. ... Regardless, the people tried getting across, got across often. And sometimes, they got caught, too.” (FN 2018_KK)
\end{abstract}

If they did not have their papers "they got in trouble. The guards, or whatever they were, some kind of customs police ... Well, the Hungarian state [had its own regime], ${ }^{21}$ Yugoslavia, too, naturally. And so, there was trouble for the people, you know ... Pay up!" (FN 2018_KK). Hungarian soldiers indeed frequently detained or fined the locals of Felsőszölnök. ${ }^{22}$

Statements of the people describing their experiences along the frontier are telling, as they reveal that "some things can only occur at borders" (DONNAN - WILSON 1999:4):

"For that first period, I don't know, before the Second War, it's hard for me to say anything.

From what I've heard from the elders, there were smuggling routes and such, ways to get across, things that happen by the border, especially by a border like this, where two different systems meet. (...) The border, though under strict control, was nevertheless alive. There was always stuff going on ... holes being poked ...” (FN 2018_SK)

Curious about the inter-war time is the statement that "[the border] had not really been there at first. People could walk to and fro, and then, it was really closed"23 (FN 2018_VK). Before the Second World War, mixed marriages between the folks of the Rába Valley and Goričko were common and one of the spouses would normally move to live with the other since "there was no border yet", and then suddenly "those weddings were no longer

19 In the nearby southern Goričko villages (Šalovci, Gornji Petrovci, Lucova), people likewise spoke the same language but were Protestant, and faith supposedly prohibited the folks of Markovci from marrying there. "[The] Protestants work on Sunday, which reflects poorly on their children," was an example of the stereotyping that alienated them from the inhabitants of Markovci, despite the priesthood's claims that "ours and theirs" was the "same religion" (BRUMEN 1992:20).

20 Aptly illustrated by a commentary on the still-perceived difference between lower Prekmurje and Goričko: "'Going to town' in lower Prekmurje means going to Turnišče, and here going to Szentgotthárd" (FN_2018_DH).

21 Information on this topic is found in the Apátistvánfalva museum. Cf. footnote 26.

22 In 1922, the newspaper Novine wrote: "As we can see, the Hungarians no longer care for us, and so we must be faithful Yugoslavs now" (cit. in KozAR 2017:25).

23 By this, the post-Cominform border is meant. 
possible, and those who married into Hungary couldn't get back after the war, they were stranded" (FN 2018_MŽ), including the many people of Prekmurje who had done so.

As long as a border regime existed in which mandatory documents still enabled the legal crossing of the border, from the perspective of the experience of that second, impenetrable border - following 1948 - it thus appeared as if the previous one was not real; this observation turns the focus to specific border techniques. If border regimes are "types of classification systems and knowledge practices that define the places in which people live and move, then the techniques [are] used to actually build, maintain, control" (GREEN 2013:355). These include travel documents, bureaucratic and legal procedures, surveillance technologies, and the management of border regimes. Their efficiency "demonstrate[s] the degree to which such techniques work to define and control places and spatial relations" (ibid.).

\section{THE IRON CURTAIN: \\ "OUR SOLDIERS WOULDN'T SHOOT IF THEY SAW YOU. THE HUNGARIANS, THOUGH..."}

After the four-year-long occupation of Prekmurje during the war, the Trianon border was restored. Already in February 1945, in addition to its military, the temporary Hungarian national government organized the Service for Border Control to combat criminal and smuggling activity. If locals on the Yugoslavian side at first believed the border was rather porous,${ }^{24}$ the situation "in the following years (...) worsened dramatically" (Kozar 2017:40). After the dispute between Tito and Stalin, it first "escalated" in an altogether visible, physical sense:

\footnotetext{
"The Hungarians, partly also due to Russian dictate, closed the border completely. They cut down the forest alongside the entire frontier, ploughed through a stretch of land several meters wide and maintained it so that tracks could be seen right away when people crossed the borderline. This barren stretch was constantly maintained, at times also by villagers from Felsőszölnök for a small payment since the task was too time-consuming for the soldiers to handle. Also, guard towers were set up, from where the complete borderline was under surveillance. (...) Of course, our own [Yugoslav] military wasn't standing around either. They patrolled the entire perimeter along a track set up some 100 meters from the frontier. This hundred-meter stretch was only accessible with a special permit." (KozAr 2017:42-43)
}

The numerous versions of people's stories give concrete substance to the condensed description above. With a border closed hermetically on both sides, a significant fact was that the border regimes on the Hungarian and Yugoslavian side were not the same, confirming the argument that border regimes and the ways state power actually operates on the border ought to be evaluated from "a localized, particularistic and territorially focused notion of borders" (WILSON - DonNAN 1998:3). The regimes differed in the scope of the frontier belt, the strictness of surveillance, movement control and penalties:

${ }_{24}$ From Martinje, for example, crossing was possible along a road towards Felsőszölnök. 
"Their people also walked along, but our soldiers weren't as nasty. If they spotted a person, they wouldn't shoot, normally. The Hungarians though, you bet!" (FN 2018_JS)

\title{
From the Slovenian side ...: "We lived a very specific youth"
}

\begin{abstract}
"After the war, there was the border again, but not entirely closed, at first. Only with that notorious Cominform, then, it got shut down and locked, and that was the regime, that there wasn't even a crossing to speak of, nothing. Tons of army, on both sides of the line. (...) For a while there were landmines, too. Later, when the two of us ... in the 80s [went across], this 100-metre strip was still there.... where the Yugoslavian army had its lookout path ... Going in there was forbidden, except if you owned a forest there, (...) you needed a special permit. Without one, off to the guardhouse you went, and you were charged a fine.” (FN 2018_KK)
\end{abstract}

The crossing permit was a critical document in the avoidance of problems with the authorities. It had to be shown to the soldiers on a regular basis. Still, when heading out to work or foraging for mushrooms, people happened to forget theirs, which meant they might get in trouble. Yugoslav soldiers were not familiar with the locals and took them to the guardhouse. The sergeant who knew them usually let them go without paying a penalty (FN 2018 KK).

Some transgressions went relatively unpunished, partly because the people and the soldiers - who were mostly from Bosnia, North Macedonia, rarely Slovenes - eventually got to know one another (FN 2018 DH; FN 2018 SB) and things would get settled with verbal warnings. At other times, the violation was sent over to the misdemeanor judge. In general, for that period, people do not have particularly negative experiences regarding the soldiers on the Yugoslav side. Much depended on the guardhouse commander: "A good sergeant usually had good soldiers." Sometimes they would even help the locals with their work in the forest and field. "And we never locked our doors, we felt safe here" (FN 2018_IH).

Adults and older people could not immediately grasp the character of this border: "they found the post-war closing of the border hard to accept, so they had a habit of crossing illegally, which could be dangerous" (FN 2018 IH). Some stuck to their usual practices, most often visits to their relatives. They snuck along the way so as not to be caught by the soldiers, though it was eventually normal to learn the schedule of the guards: "They knew, down to a minute, when the border patrols were passing a certain area" (FN 2018_JS). Worse things happened in cases of illegal crossings to Hungary, where grazing cattle would sometimes stray as well (FN 2018 DH).

Illegal border-crossings were still frequent in the 1960s and 1970 s, when the faraway crossings at Dolga Vas and Hodoš were opened. People continued to secretly visit their relatives in nearby Rába Valley villages, sometimes stopping at a store or inn, and they also smuggled goods. What contraband the Slovenians preferred to move is not clear. This was generally kept a secret. The ground along the border belt was kept freshly turned over once or more in a year, "and every two weeks or so, it was raked flat and even, so you could see the footsteps of anyone sneaking over (...) people got the idea of crossing in reverse, backpedaling, so it appeared like it was someone from the other [Hungarian] side; people had their tricks and clever ways" (FN 2018_JS). 
When the people of Goričko wished to travel to Hungary, they passed through Hodoš, but if they wanted to go to the Rába Valley it was a long way off, and the border surveillance was very strict as well. Entering Hungary entailed a mandatory currency exchange-not from Yugoslav dinars but foreign currencies, mostly the Austrian schilling, as well as numerous checkpoints on the Hungarian side. In the 1970s and 1980s, in addition to familial ties, shopping was a significant motive to visit Hungary due to the considerably lower prices of certain commodities (e.g. cheese).

The hermetic border was eventually internalized by the people, especially those who were already born into it:

"I grew up here, right by the border, at the frontier belt, that 200-metre belt, and we were brought up not to go and look, not to walk there (...), not to even think that there was another world there, [we were] warned that there was a physical obstacle, $(\ldots)$ that there were soldiers, right. (...) For quite a while we were growing up in this ghetto of sorts, walled off on one side, entirely. (...) there were no roads, no motor vehicles (...) so we [lived] a very specific youth." (FN 2018_SK)

\title{
From the Hungarian side...: "The eyes have no borders"
}

\begin{abstract}
“There by the border, in the village, how to say it, life wasn't easy (...) We were a little scared of the soldiers. They stayed by the border, guarding, patrolling the road down there. (...) That feeling of constantly being watched (...). People couldn't get to their houses in peace. Even though they knew us, they'd be asking us where we're going, who we are, and what business we have going there. (...) Working, you're being watched. Walking in the direction of the border, you're being asked questions. Coming back home, more questions. Why, where from? It was no use repeating we lived there, right there on the bank. (...) There was a soldier apiece standing guard at the start and the end [of the village], so they stopped us from whichever direction we were coming. They wanted the pass. (...) For us, it was just normal, back then. That there were border guards there, that they kept bothering us, that we had to carry passes and show them or there would be problems. (FN 2018_VK)
\end{abstract}

The account illustrates the differences between the border regimes on the Hungarian and Yugoslavian side. In addition to many other testimonies describing the restrictions or prohibition of movement, interventions appeared to hurt most what was closest to the people - home and family. In this context, canonical in the local memory (heard not just from a descendent but from several other villagers as well), is the following story: "When grandma's mom died in Markovci, they wouldn't let her go back there. She was at home in Andovci, and she could hear her mother's funeral bells ringing in the Markovci church, she was crying her eyes out as her mom was getting buried, (...) they wouldn't let her go." (FN 2018_VK) 
The frontier belt regime is described in detail in the Apátistvánfalva museum: ${ }^{25}$

\begin{abstract}
"In 1950, physical barriers were set up along the border, a barbed wire fence on both sides with a restricted perimeter in between, and a 10-meter wide minefield. Based on Regulation nr. 16/1950 IV of the chief department of the Ministry of Internal Affairs, on 20 June 1950 a 15-kilometre-wide frontier zone was established on the border with Yugoslavia. The same measures were expanded on 1 September 1952 to the Austrian border with Regulation nr. 0390/1952. Within the frontier zones, a $2 \mathrm{~km}$ wide surveillance strip was defined, and within the strip a 50 to 500 -meter wide border perimeter. Certain zones or areas could only be entered with written permits of the police or the border surveillance service, and only guards were permitted to stay in the 50-meter restricted perimeter. The escalations caused considerable unease among the border population. Poor conditions in the party leadership and the state, coupled with an air of constant suspicion, also affected the work of the Border Surveillance Service." (SPOMENIK graničarjem, V04)
\end{abstract}

Interviewees also speak of the 15-kilometer area of the frontier zone and its various sections, depending on the distance from the border proper. The border thus was not just a frontier between Yugoslavia and Austria. There were specific boundaries present all across the Rába Valley and its margins (FN 2014_MM). In Felsöszölnök, for example, the wire marking the borderline with Austria was initially planned straight through the village. However, the authorities abandoned the original plan due to rough terrain and resistance from the villagers. The villagers had to agree that the entire village would be under constant surveillance and strict control during passage between parts of the village (FN 2018_MR).

Specific permits were required for daily movement around the border region. The documents, which had to be kept on one's person at all times, were various: some were proof of residency by the border, confirmed annually; a slip with a red strip, for example, was a work pass (FN 2014_MS). A narrator from Gornji Senik, who was studying in Györ at the time, needed as many as five different permits to visit his home village (FN 2018 MR). Permits were also required to work on the fields or in the woods near the border — these had to be approved weekly, or even daily (FN 2014_VG). "We couldn't go near the state border proper, anyway. It was all cleared-out land there, wires, landmines for all I know"26 (FN 2018_MR); they "picked them up" in the early 1960s. On the Hungarian side, under the soldiers' watch, work brigades of locals, mostly women, who made some money that way, maintained the clearing alongside the border. Some used it as an opportunity to very loudly communicate some news with people from Felsöszölnök who illegally crossed the border with Austria. In front of the soldiers who did not understand Slovenian, they justified the shouting by pretending that some woman was having trouble with hearing (FB_2018_MR).

\footnotetext{
25 In the Border Guard Memorial in Apátistvánfalva (popularly called the Iron Curtain Museum), officially named Határör Emlékhely, an exhibition on the life of border guards was set up outdoors and in a former guardhouse in 2007. For its local visitors, visits to this memorial function as memory trigger.

26 Some say these were not placed on the Yugoslavian side.
} 
Officially, it was forbidden not only to shout but even gaze across the border, and so for example, a soldier ordered some woman who had been looking to cease. "She replied: "A szemnek nincs határa" [The eyes have no borders] (FN 2018_MR; cf. PŠAJD 2007:31, 113; SEDAR 2014:53). This statement, too, spread among people's narratives as a fitting metaphor for the power of repression and resistance against it.

As always during times of hardship, the people managed. A lot depended on the relationship they maintained with the military or the border guards: "Some even helped us. They had means of transportation, trucks, horses, and they helped out the farmers. And there were also some who were very bad-tempered." The guards were, of course, being rotated, especially if someone was found to have illegally crossed the border. During the 1950s and later as well, many people of the Rába Valley did indeed flee over the Austrian border: "And none of them were caught, thank god. They knew exactly where they could get through, and when. The soldiers were punished instead, locked up, even (...) In time, we knew exactly where the soldiers were patrolling, and when they were changing shifts.” (FN 2918_MR)

The border guards were

\begin{abstract}
"from other parts of Hungary. The reason was so they wouldn't know the locals, so they wouldn't have relatives here. (...) Most of them were alright. They were a little annoyed over not understanding us. Some of them even learned a few Slovenian words. (...) There were families, though, where the soldiers liked to stop, linger, talk. (...) Of course, most of these had (...) girls around." (FN 2018_MR) ${ }^{27}$
\end{abstract}

There was a noticeable difference between the borders with Austria and Yugoslavia in general:

"After ' 57 , yes, the minefields were removed from the Yugoslavian border. That is, after the revolution in Hungary (...) Tito and Kádár then signed a friendship treaty between Yugoslavia and Hungary, yes, and then all the mines were removed, they just left that double barbed wire and the cleared-out belt. (...) the Austrian border was still tightly secured up until '89. (...) It was quite a particular system, (...) this stuff on the Austrian border was electronic (...) in the end, and Yugoslavia wasn't considered one of the capitalist states, yes. And so, at their frontier things got a little bit more relaxed (...) after '57 already. (FN 2014_MS)

An older woman ascribed the more open relations with Yugoslavia to Tito: "Tito was a lot smarter because during Tito's time people could already go work in Austria. Us - God forbid! We couldn't even look at the Austrian side or come near, or they'd pack us into prison (...) That's that, I'm telling you. A good man!" (FN 2014_VG)

Throughout the 1970s, mutual contacts also amplified due to the implementation of border passes, but the border could still be an unpleasant place:

“They kept an eye on us real close (...) They knew we were Slovenians. (...) Crossing the border, for me and especially for the elderly, was very stressful. Coming back [from visits in

27 Several women from the Rába Valley married Hungarian soldiers, boasting of being well off, which later turned out to be false. 
Slovenia], people didn't talk so much about the beauties of Slovenia but rather about what pretty things they managed to hide on the bus, and where. Smuggling, that was the greatest 'adventure'.” (FN 2018_MR)

Experiences and memories of border life are interspersed with terms like army, border guard, barbed wire, post, guard tower, landmine, patrol, gunfire, restricted, illegal, etc. These signifiers instilled fear into the people that eventually coalesced into a generational phenomenon - apprehension for the older generations, and for the younger an accepted, unquestionable impediment - a topic surrounded by silence.

\footnotetext{
"You weren't supposed to talk about it, I mean, when we were kids, yeah, you were kind of born into that situation, that Iron Curtain and so on. It was mostly the older people who were anxious about it, or telling us what it was about since we considered it just another fact of reality. It was self-evident, we lived in a world like that, and that was it.” (FN 2014_MS)
}

"They were silent for a long while (...). They weren't telling many stories ... it was all supposedly ok, they were working, working themselves to death. (...) I never heard my family discussing these things. As a kid, for me, it was simply the place I grew up in. (...) I wasn't asking why. The system just ran that way, and we adapted. We were used to it.” (FN 2014_MM)

\section{A BORDER NO MORE?}

Talking about the border burgeoned after 1989, when the repressive border regime began dissolving and with it the fear that had kept people quiet. From this silence sprang forth not only people's remembrance and narratives, being now collected in the archives of scholars, but also many research projects, publications, media reports, public events and memorial objects characteristic of all the places that were the historical settings of the Iron Curtain..$^{28}$

In the Board Guard Memorial in Apátistvánfalva, a concise record is presented on the border management practices of the Hungarian state between the 1950s and 1990s of the past century, and on the gradual suspension of the frontier regimes and techniques. ${ }^{29}$ In June 2019, on the Slovenian side, in the restored guardhouse in Čepinci (Šalovci municipality), the museum in Apátistvánfalva was joined by the curated museum collection "Guardians of the Frontier", advertised as a landmark or "tourist product" (cf. Ispán 2019) on the "Mura Raba Tour", established in cooperation with the Military Museum of Slovenian Armed Forces.

${ }_{28}$ In this contribution, we omit the many certainly relevant comparisons provided by extensive ethnological and anthropological studies on European borders, especially those along the Iron Curtain, on border populations and their (collective) memories. See e.g. Meinhof 2002; Rose 2004; Spalová - Grygar 2006; Zhurzhenko 2011; Green 2012a, 2012b, 2013; Straczuk 2012; Lechevalier - Wielgohs 2013; Komska 2015; Macdonald 2013; OATES-Indruchová - Blaive 2015; Donnan et al. 2017; LAINE et al. 2018; MóD 2019.

29 Exhibition panels V04-V07. 


\begin{abstract}
"Aided by images and writings, and especially the authentic exhibited pieces, the museum visitor may gain a glimpse into the life of the locals, soldiers and policemen at and by the border throughout the decades, and with it the various political systems that so profoundly shaped the destiny of these people." (Museum collection - Guardians of the Frontier, exhibition board text; cf. PoJBIČ 2019)
\end{abstract}

The removal of the physical barriers and measures characteristic of strict border surveillance began in 1989. It was the final act of a long process of change in Europe, a final step in a sequence of administrative measures that likewise affected the regime by the Hungarian border with Yugoslavia and Austria. Changes running from the 1960s on were especially significant as they made a legal crossing of the border easier, though the crossing-points themselves were relatively distant from the border villages of the Rába Valley and Goričko. The crossing at Hodoš-Bajánsenye was on both sides used most often for family meetings or visiting relatives, and also for shopping purposes. For the Slovenians in the Rába Valley, the opening of this crossing also affected their social organization. At that time, they did not have minority organizations yet, ${ }^{30}$ but on the level of inter-state agreements they were now able to develop better cooperation with Slovenia through organized trips and frequent appearances of their folklore and choir groups there.

With the 1989 turning point, the self-evident presence of unease, the existential experience of a restricted and controlled life, resignation to a reality set for the people by the global politics between the European West and East - materializing in a hermetic border - , symbolically began waning in the lives of the border population. In the processes of democratization sweeping across the socialist states, eventually resulting with the end of the Cold War and the fall of the Iron Curtain (symbolized on the European level by the Pan-European Picnic), the triple border area between Yugoslavia, Hungary and Austria witnessed its own act of symbolic reconciliation, the Meeting of Friendship, which represented the first opening of the border in the Iron Curtain (more in GRÁFIK 2001). It was organized by the Hungarian People's Front and three border municipalities, Körmend, Murska Sobota and St. Martin an der Raab:

\footnotetext{
"A meeting on the triple border. (...) It was something I'll never forget as long as I'm alive. Back then, we couldn't imagine something like that actually taking place. The Austrians, especially, had been reluctant. Worried. (...) What happens, yeah? If a few thousand people start walking towards Austria (...) Are they going to just shoot, or what? It was strange that our own soldiers were in plainclothes. No uniforms... (...) This meeting [was] a great chance to socialize between the families. People cried. (...) The borders, though, were still there. We all had to go back." (FN 2018_MR)
}

30 They were connected into the Democratic Association of South Slavs already established in Hungary in 1947, which fostered cultural-political-organizational and informative-educational work, and the recognition of the rights of ethnic minorities. Slovenians in Hungary left the association in 1990, founding the Association of Slovenians in Hungary in Szentgotthárd. In addition to this organization, the National Self-Government of Slovenians has been active since 1995 in Felsöszölnök (with an office in Budapest), representing a political and economic liaison with the Hungarian state. 
Then not only Slovenia, Yugoslavia and broader Eastern Europe, but also Hungary experienced a tide of political-ideological change. As our collocutor believes, the organizers must have had permission to stage the walk (FN 2018_MR).

\footnotetext{
"Certain politicians were already working on change; we knew there' $\mathrm{d}$ be changes by the border eventually. (...) But I still find it striking (...) how they could put that meeting together so fast, they must have been talking about it before. And trusting these people here, too (...) if people decided to keep on going and stay in Austria, they'd all be able to get 'politikai menedékjog' [political asylum] (...) They were eligible since this place still had a communist regime." (FN 2018_MR)
}

That a shift had been delineated for some time is also evident from the Hungarian government proposal of March 1989, based on the assessment of the political commission of the Hungarian Socialist Workers' Party (MSZMP) of February 1989:

\footnotetext{
"Several restrictive measures implemented 30-40 years ago, which served border surveillance, have become unsustainable. The political commission agrees with the notion of gradually eliminating the 'surveillance strip', measures, in the west also the warning system (...) In passport control, recruiting soldiers will be gradually replaced by professionals." (SPOMENIK graničarjem, V010)
}

By 1 August 1990, the surveillance and frontier zones were abolished, and the Hungarian citizens were via an act adopted in 1989 ensured the civic right of possessing a passport and travelling the world.

\section{IN CONCLUSION: THE "PRESENCE OF THE PAST"}

Thus ended the story of the eight decades of the border that is no more. The following two decades require separate research. The events and the spirit of this age are to a great extent woven into the present narratives of the past: field research is inherently "presentistic", as the "now" or "present" constitute its heuristic and analytical aspect. As we outlined a condensed map of the "facts" on Slovenian-Hungarian border shifts (Munda HirnöK - SlaveC GradišNiK 2019, 2020), which today still divides Slovenia and Hungary on the map, it was not our intent to thematize and problematize the frequently stressed contrast or tension between history and memory. The relation between these two concepts depends not only on their heterogeneous theorizing in historiography and memory studies but is fundamentally ambivalent — in scholarship and everyday use - along a fundamental axis. Is history a verified past (scientifically, objectively etc.) - in contrast to the individual (and collective) memory that is supposed to be relatively unreliable and expressed in unverifiable narratives - and thus the carrier of rational primacy, or is history a relatively disputable scripted canon versus the subjective honesty (truthfulness, integrity) of memory? The latter, to note, has been increasingly substantial in research, also as a consequence of the general proclivity of social sciences and humanities towards the constructivist paradigm and the subjective (MACDONALD 2012:234). 
To avoid the definitional and conceptual enticements posed by the concepts of history, (collective, social) memory, heritage, historical consciousness etc. (cf. MACDONALD 2012:234-235; 2013:3-17; KõReSAAR 2014), Sharon Macdonald proposed the concept of "past presencing" which "draws attention to the multiple ways in which the past may be (and is made to be) present - as well as represented - whether articulated verbally or experienced and performed in other ways" (MACDONALD 2012:235). Ethnographic studies disclose the manifold ways people "construe particular histories for themselves, choose to commemorate certain events and ignore others or express relationships between past, present, and future in their daily lives" (ibid.: MACDONALD 2012:234). The ways of understanding are diverse, often at odds with one another, and show themselves in different forms of historization. In the methodological sense, the concept of past presencing focuses on a diversity of sources (fieldwork, archives, museums, material testimonies, rituals, narratives etc.) and is anthropologically saturated as it is interested specifically in the bonds between people's pasts and the presents, or the presence of the past.

In this light, the past is no mere a prelude to the now but entails engaging ways or means through which it is selectively reproduced - alongside remembrance and forgetting (cf. MACDONALD 2013). Accordingly, the narratives of our subjects are the narratives of their present, which some of them distinctly stressed when discussing the silence that had paralyzed the older generations up until the time when the border could be freely spoken on. "And maybe not all be might true. Everyone added something, and some [things] were actually happening" (FN 2018_MR). Due to the long silence and the restricted, episodic — or autobiographical - memory of our interviewees, reaching back no further than the post-Second World War period, we added to their narratives a few comments from published sources.

Narratives on the border between Goričko and the Rába Valley, related through the proximity of the villages whose people speak the same language, vary in their content and emotional charge. After the establishment of the Trianon border, their protagonists have been separated in their historical experience and identity: Slovenians in the Rába Valley are a group with at least two affiliations-Hungarian citizenship and Slovenian nationality, which in the circumstances of minority life preserved itself primarily through language. Their stories of the border, expressed for the most part in their vernacular, have preserved and still preserve their community. That is why they are not only the narratives about the state/states and their power; they also narrate the people, as reaffirmed by the circulation of stories and the recurrence of specific events, which (were) experientially most profound to the individuals. Since they shared a common fate, and continue to share it as a minority to this day, it is reasonable to say their community maintains itself through a specific semantic memory. For them, the Iron Curtain of 1948 was not a single border, but rather a border with Yugoslavia and another with Austria, multiplied by the various surveilled zones in Hungary, and so the Rába Valley ever remained a "dead end", but not in the geopolitical sense. For the people of Prekmurje, greater significance lays with the Trianon border, which had cut across the former Slovenian March and reshaped their social communication space, though they in time, already during the two wars and despite being long positioned at the Yugoslavian or Slovenian periphery, more easily adapted to the new conditions, redirecting their social and commercial routes towards Slovenia. This also explains why, in general, the people 
of Goričko ${ }^{31}$ felt the border as less limiting, except for those Goričko villages in the closest proximity to the Hungarian border, where it intruded on their forest or land properties and kinship ties. There, individuals remember the border's manifestations in the landscape - barren ground, secretive woods, forbidden routes and overgrown roads. In short, the divided places of the hitherto connected Slovenian March were compelled to redefine themselves in terms of politics, administration, economy, communication, culture and identity. These redefinitions are also an on-going process in the new life circumstances of the Schengen Area of the European Union.

The life of people by the Slovenian-Hungarian border reflects the tension between "the fixed, durable and inflexible requirements of national boundaries and the unstable, transient and flexible requirements of the people" (DonNAN - WILSON 1999:1). Borders are always imposed on the people. "Few things were solved in the natural landscape, or here, they were decided far away, these borders were ..." (FN 2018_SK) — and restrict movement. "Yes, it's different, you were always going one way. In central Slovenia they can't really know how it feels, they can travel in any direction they like. I'm sure they don't even think about it, but here, you always had to think ..." (FN 2018_KK). Of course, people also resist - through clandestine shortcuts, through finding ways of interacting with their families, through smuggling goods, in their recurring desire, not least, to visit the nearby village from where the bell is heard ringing (FN 2018_KK), or walk to the Tripoint (FN 2018_MR).

Then, when the border is gone, "you don't know what to do with that great big freedom, suddenly" (FN 2014_MS); no-border likewise reshapes the view of the past or shifts perspective, unveiling the emotions (cf. SVAŠEK 2000) and ambivalences of daily life:

\begin{abstract}
"You're living, I don't know for how long, under that Iron Curtain, in the shadow of that curtain actually, and then one day it just opens up (...) and you're simply not ready. (...) And then, well, the kids nowadays, they haven't experienced that old system and so they can't really appreciate the freedom. Older generations were again upset, in a way: is this now going to be good for us, or is it going to be bad for us? Let's remember, after all, when in '89 it fell, the Iron Curtain, then some of the elders were downright nostalgic for the old, secure times, when things were under guard and in order (...) There was no reason to fear strangers, no foreigners could come here, and so we kept our houses open, our doors unlocked, no worries. Some have fond memories of that time, they say it was a good time. So, it's not a simple matter, really, it's no simple thing. (...) Though it's physically no longer there, you know, the border, I think it's still there in a way, in the people's minds." (FN 2014_MS)
\end{abstract}

Since time immemorial, borders have been created, institutionalized and systematically maintained, opened and closed all over the world, constantly changing political, economic and social life. The open Slovenian-Hungarian border is now foremost a challenge in bringing the landscape closer in economic, ecological, social and cultural aspects. Regional cooperation, already encouraged by European economic policy in the $1960 \mathrm{~s}$ and $1970 \mathrm{~s}$, spreading widely in the 1980s and 1990s, only became a reality here following the accession of both states to the EU and their inclusion into the Schengen

31 This is also supported by narratives collected in the broader area of Goričko by students participating in our project. 
Area (see BAJUK SENČAR 2019). In this, too, inhabitants on both sides of the invisible border see and are already taking advantage of new opportunities, yet always dealing with the difficult heritage (MACDONALD 2009) and their fringe position, one for which they now no longer blame the border, but rather the state.

\section{REFERENCES CITED}

BAJUK SENČAR, Tatiana

2019 Cross-Border Cooperation and the Europeanization of the Slovenian-Hungarian Border Region. Traditiones 48(1):213-231. https://doi.org/Traditio20190109

BRUMEN, Borut

$1992 \mathrm{Na}$ sončni stran Alp in drugi strani reke Mure [On the Sunny Side of the Alps and on the Other Side of the River Mura]. In Brumen, Borut (ed.) Etno delavnica Markovci 91, 5-23. Ljubljana: ZOTKS, Gibanje Znanost mladini.

Donnan, Hastings - WiLson, Thomas M.

1994 Border Approaches: Anthropological Perspectives on Frontiers. Lanham, MD: University Press of America.

1999 Introduction: Borders, Nations and States. In Donnan, Hastings -Wilson, Thomas M. (eds.) Borders: Frontiers of Identity, Nation and State, 1-17. Oxford, UK, and New York: Berg.

Donnan, Hastings - Hurd, Madelaine - Leutloft-Grandits, Carolin (eds.)

2017 Migrating Borders and Moving Times: Temporality and the Crossing of Borders in Europe. Manchester: Manchester University Press. https:/www. jstor.org/stable/j.ctt1wn0rz3.7

ERLL, Astrid - NüNNING, Ansgar (eds.)

2010 A Companion to Cultural Memory Studies. Berlin in New York: De Gruyter.

FIKFAK, Jurij - MÉSzÁRos, Csaba

2019 Protected Areas on the Slovenian-Hungarian Border: A Place and Space of Nature and Culture. Traditiones 48(1):7-26. https://doi.org/10.3986/ Traditio2019480101

GRÁFIK, Imre

2001 Tromeja: Od srednjeevropske nacionalne travme do stičišča narodov [Triple Frontier - From Central European National Trauma to Meeting-Place of Peoples]. Etnologija Slovencev na Madžarskem = A Magyarországi szlovének

GreEN, Sarah néprajza 3:9-32.

2012a A Sense of Border. In: Wilson, Thomas M. - Donnan, Hastings (eds.) $A$ Companion to Border Studies, 573-592. Malden, MA, and Oxford, UK. https://doi.org/10.1002/9781118255223.ch33

2012b Reciting the Future. HAU 2(1):111-129. https://doi.org/10.14318/hau2.1.007

2013 Borders and the Relocation of Europe. Annual Review of Anthropology 42:345-361. https://doi.org/10.1146/annurev-anthro-092412-155457 
IsPÁn, Ágota Lídia

2019 Transformation of a Strictly Controlled Border Area into a Tourist Destination: Making Heritage in Communist Hungary. Traditiones 48(1):77-100. https:// doi.org/10.3986/Traditio2019480103

Komska, Yuliya

2015 The Iron Curtain: The Cold War's Quiet Border. Chicago: The University of Chicago Press.

KõRESAAR, Ene

2014 Concepts around Selected Pasts: On 'Mnemonic Turn' in Cultural Research. Folklore 57:7-28. https://doi.org/10.7592/FEJF2014.57.koresaar

KošTrIC, Sandra

2011 Od »slovenske Sibirije« do čarobne pokrajine neskončnih ravnin: Prekmurje $v$ kontekstu slovenske nacionalne identitete. Diplomsko delo [From 'Slovenian Siberia' to Magic Region of Infinite Plains: Prekmurje Region in the Context of Slovenian National Identity. BA Thesis]. Ljubljana: Univerza v Ljubljani, Fakulteta za družbene vede.

Kozar, Ciril

2017 Martinje: Vas pod Srebrnim bregom [Martinje: A Village under the Silver Slope]. Martinje: GOR-STOR d.o.o.

LaIne, Jussi P.- LiIKanen, Ilkka - Scott, James W. (eds.)

2018 Post-Cold War Borders: Reframing Political Space in the EU's Eastern Europe. London: Routledge.

LeCheVAlier, Arnaud - Wielgohs, Jan (eds.)

2013 Borders and Border Regions: Changes, Challenges and Chances. Bielefeld: Transcript Verlag. https://www.jstor.org/stable/j.ctv1 fxhcq

Low, Setha M. - LAWrence-ZúÑIGA, Denise (eds.)

2003 The Anthropology of Place and Space: Locating Culture. Malden, MA: WileyBlackwell.

MACDONALD, Sharon

2009 Difficult Heritage: Negotiating the Nazi Past in Nuremberg and Beyond. London - New York: Routledge.

2012 Presencing Europe's Past. In Kockel, Ullrich - CRAITH, Máiréad Nic Frykman, Jonas (eds.) A Companion to the Anthropology of Europe, 233-252. Malden: Wiley-Blackwell.

2013 Memorylands: Heritage and Identity in Europe Today. London - New York: Routledge.

MeINHOF, Ulrike Hanna (ed.)

2002 Living (with)Border: Identity Discourses on East-West Borders in Europe.

MóD, László Aldershot: Ashgate.

2019 "A Border that divides and connects": Monuments and Commemorations on the Slovenian-Hungarian Border. Traditiones 48(1):101-116. https://doi. org/10.3986/Traditio2019480104 
Munda HirnöK, Katalin - MedvešEK, Mojca

2016 Čezmejna mobilnost porabskih Slovencev [Cross-Border Mobility of the Porabje Slovenians]. Traditiones 45(3):89-111. https://doi.org/10.3986/ Traditio2016450305

Munda HiRnÖK, Katalin - SLAVEC GRADIŠNIK, Ingrid

2019 Meje in spomini nanje [Borders and Border Memories]. Traditiones 48(1):2775. https://doi.org/10.3986/Traditio2019480102

2020 Slovenian-Hungarian Border: A Historical Outline. Acta Ethnographica Hungarica 65(2):333-354.

Newman, David

2011 Contemporary Research Agendas in Border Studies: An Overview. In WASTLWalter, Doris (ed.) The Ashgate Research Companion to Border Studies, 3347. London: Routledge. Available at: https://www.routledgehandbooks.com/ doi/10.4324/9781315612782.ch2

OATES-INDRUChOVÁ, Libora - BlaIVE, Muriel

2015 Border Visions and Border Regimes in Cold War Eastern Europe. Journal of Contemporary History 50 (3):656-659. https://doi. org/10.1177/0022009415592687

PoJBič, Jože

2019 Spomini z obeh strani železne zavese [Memories from both Side of the Iron Curtain]. Delo 27(6) https://www.delo.si/magazin/zanimivosti/spomini-zobeh-strani-zelezne-zavese-199137.html (accessed August 30, 2019)

PŠAJD, Jelka

2007 Če klonkaš, sa ti opre: Življenjske zgodbe iz Porabja [If You Knock, It Opens: Life Stories from the Rába Valley]. Murska Sobota: Pokrajinski muzej Murska Sobota.

RAVNIK, Mojca

1999 Družina in sorodstvo v slovenskem Porabju, v Prekmurju in slovenski Istri [Family and Kinship in Slovenian Raba Region, Prekmurje, and Slovenian Istria]. Traditiones 28(1):331-342. http://www.dlib.si/?URN=URN:NBN:SI: doc-PJFNW2ND

Rose, Brian

2004 The Lost Border: The Landscape of the Iron Curtain. Princenton: Princeton Architectural Press.

SEDAR, Klaudija

2014 Cerkvena ureditev Prekmurja skozi čas [Church Organization in Prekmurje through Time]. In Godina Golisa, Maja (ed.) Prekmurje - podoba panonske pokrajine, 141-154. Ljubljana and Petanjci: Založba ZRC, ZRC SAZU.

Sevastianov, Sergei V. - Laine, Jussi P. - Kireev, Anton A. (eds.)

2015 Introduction to Border Studies. Vladivostok: Dalnauka.

SPAlová, Barbora - GrYGAR, Jakub (eds.)

2006 Anthropology at Borders: Power, Culture, Memories. Praga: FHS UK a MKC Prague.

SpOMENIK graničarjem. Razstavni panoji V01-V10 [Border Guard Memorial, Exibition panels V01-V10]. 
STRACZUK, Justyna

2012 Local Practices of European Identity on the New Eastern Borders of the EU. In Kockel, Ullrich - Craith, Máiréad Nic - Frykman, Jonas (eds.) $A$ Companion to the Anthropology of Europe, 199-211. Malden, MA: Wiley Blackwell.

SVAŠEK, Maruška

2000 Borders and Emotions: Hope and Fear in the Bohemian-Bavarian Frontier Zone. Ethnologia Europaea 30(2):111-126. https://doi.org/10.16995/ee.910

SVENŠEK, Ana

2019 Porabje: Samosvoj košček zemlje, kjer kljub vsemu še živijo Slovenci [The Rába Valley: A Distinctive Piece of Land where, inspite everything, Slovenians still lives]. https:/www.rtvslo.si/prekmurje/porabje/porabjesamosvoj-koscek-zemlje-kjer-kljub-vsemu-se-zivijo-slovenci/479500 (accessed October 15, 2019)

WASTl-Walter, Doris (ed.)

2011 The Ashgate Research Companion to Border Studies. London: Routledge.

WILSON, Thomas M.

2012 The Europe of Regions and Borderlands. In Kockel, Ullrich - Nic CRAITH, Máiréad - Frykman, Jonas (eds.) A Companion to the Anthropology of Europe, 163-180. Malden, MA: Wiley Blackwell.

Wilson, Thomas M. - Donnan, Hastings

1998 Nation, State and Identity at International Borders. In Wilson, Thomas M. Donnan, Hastings (eds.) Border Identities: Nation and State at International Frontiers, 1-30. Cambridge: Cambridge University Press.

Wilson, Thomas M. - Donnan, Hastings (eds.)

2012 A Companion to Border Studies. Malden, MA: Wiley Blackwell.

Zhurzhenko, Tatiana

2011 Borders and Memory. In WAStl-Walter, Doris (ed.) The Ashgate Research Companion to Border Studies, 63-84. London: Routledge. 
Ingrid Slavec Gradišnik, ethnologist, is a research advisor at the ZRC SAZU Institute of Slovenian Ethnology, where she has been employed since 2001. The main topics of her research include general and regional ethnology, historical ethnology, theory and methodology, culture, identity, rituals, cultural heritage and ethnological lexicography. She led the bilateral research project Mobility, Adaptation and Integration along the Slovenian-Hungarian Border (2013-2015, project partners: ZRC SAZU Institute of Slovenian Ethnology and Institute of Ethnology, Research Center for Humanities, Hungarian Academy of Sciences). E-mail: ingrid.slavec-gradisnik@zrc-sazu.si

Katalin Munda Hirnök, ethnologist, is a research advisor at the Institute for Ethnic Studies in Ljubljana, where she has been employed since 1991. Her research focuses mainly on issues related to Slovenians in Hungary in Porabje and outside the autochthonous settlement areas, i.e., legal, socio-political, socio-economic and linguistic issues, internal migration, recent history, biographies; the cultural heritage of Slovenians in neighboring countries and the role of culture and media in inter-ethnic relations in border regions. From 2009 to 2012, she led the research project Porabje Slovenes in the "Hungarian Gulag" and collaborated on the bilateral research project Mobility, Adaptation and Integration along the Slovenian-Hungarian Border (2013-2015). E-mail: katalin.hirnok@inv.si

Open Access. This is an open-access article distributed under the terms of the Creative Commons Attribution-NonCommercial 4.0 International License (https://creativecommons.org/licenses/by-nc/4.0/), which permits unrestricted use, distribution, and reproduction in any medium for non-commercial purposes, provided the original author and source are credited, a link to the CC License is provided, and changes - if any - are indicated. 